\title{
RELATIONSHIP BETWEEN LOW BORN WEIGHT (LBW) AND STUNTING EVENTS IN CHILDREN (AGE 24-59 MONTHS)
}

\author{
Sutarto $^{1}$, Sri Agustina, Kinanti Rahmadhita ${ }^{2}$, Susianti ${ }^{3}$, Roro Rukmi Windi Perdani ${ }^{4}$ \\ ${ }^{1}$ Bagian Ikkom, Faculty of Medicine, University of Lampung \\ ${ }^{2}$ Doctor Education Study Program, Faculty of Medicine, University of Lampung \\ ${ }^{3}$ Department of Histology, Faculty of Medicine, University of Lampung \\ ${ }^{4}$ Children's Section, Faculty of Medicine, University of Lampung
}

sutarto@fk.unila.ac.id

Keywords : Low Birth Weight (LBW), stunting, toddlers.

Abstract : Background: Stunting is a condition of toddlers who have less length or height compared to age. Toddler stunting is a chronic nutritional problem caused by many factors, one of which is LBW. Babies born with LBW will be at high risk of morbidity, mortality, infectious diseases, underweight and stunting in the early neonatal period to childhood. The purpose of this study is to determine the association between Low Birth Weight (LBW) with the incidence of stunting in toddlers (aged 24-59 months) in the Way Urang Community Health Center in South Lampung Regency.

Method: This study uses an observational analytic method with a case control study design. LBW data is secondary data obtained by looking at the birth weight data of children under five listed in the Maternal and Child Health book Way Urang Community Health Center data. The statistical analysis uses the Chi Square test.

Result: There is an association of Low Birth Weight (LBW) with the occurrence of stunting in toddlers (aged 24-59 months) in Way Urang Community Health Center South Lampung Regency. P value= 0,024.

Conclusion: There is a significant association of Low Birth Weight with the incidence of stunting in toddlers (aged 24-59 months) in the Way Urang Community Health Center in South Lampung Regency. Complementary feeding of breastfeeding for a child for six months (growth mass) is very effective in overcoming stunting, which is accompanied by an increase in the quality of health examination services (ANC) during pregnancy and delivery at health care facilities.

\section{INTRODUCTION}

Stunting is a condition of toddlers who have less length or height compared to age. This condition is measured by a length or height that is more than minus two standard deviations from the WHO median growth standard for children. Toddler stunting includes chronic nutritional problems caused by many factors such as socio-economic conditions, maternal nutrition during pregnancy, illness in infants, and lack of nutritional intake in infants. Toddlers with stunting in the future will experience difficulties in achieving optimal physical and cognitive development (Kementerian Kesehatan Republik Indonesia 2018).

Adequate nutrition during infancy and early childhood is essential for the development of every child's full potential. It is well recognized that the period from birth to two years of age is a "critical window" for promoting optimal growth, health, and behavioral development. Longitudinal studies consistently show that this is the peak age for growth failure, deficiencies of certain micronutrients, and childhood illnesses such as diarrhea. After a child reaches 2 years of age, it is very difficult to reverse the stunting that has occurred before.

The incidence of stunting (short) children is a major nutritional problem facing Indonesia. Based on
The Nutritional Status Monitoring data for the period 2015 to 2017, stunting has the highest prevalence compared to other nutritional problems such as malnutrition, underweight and obese. The prevalence of short children under five in Indonesia tends to be static. Based on the results of the Basic Health Research 2007, the prevalence of stunting under five in Indonesia is $36.8 \%$. In 2010, there was a slight decrease to $35.6 \%$. However, the prevalence of stunting has increased again in 2013, namely to $37.2 \%$. The prevalence of short children under five is then obtained from the results of the Basic Health Research 2018 which is also a measure of the success of the programs that have been pursued by the government. The Nutritional Status Monitoring survey was conducted as a monitoring and evaluation of program activities and achievements. Based on the results of t The Nutritional Status Monitoring 2015, the prevalence of stunting in Indonesia is $29 \%$. This figure has decreased in 2016 to $27.5 \%$. However, the prevalence of stunting has increased again to $29.6 \%$ in 2017 (Kementerian Kesehatan Republik Indonesia 2018). The prevalence of stunting increases with increasing age at ages 0 - 11 months by $19 \%$, ages $12-23$ months by $36 \%$ and ages 24-35 months by 44\%, mostly because many toddlers who become stunted are not done growing up to reach height the appropriate child based on his age (Beatty et 
al. 2017). Children who are stunted or malnourished have a negative impact on the economy, including productivity, employment status and wages. Stunted toddlers may appear normal in the social aspects of everyday life, but in fact, children who are stunted from the start are more behind in cognitive and motor aspects (Casale, Desmond, and Richter 2014). The prevalence of stunting of children under five, which was collected by the World Health Organization (WHO) released in 2018, states that Indonesia is one of the third countries with the highest prevalence in the South-East Asian Region after Timor Leste (50.5\%) and India (38.4\%), namely by $36.4 \%$. The prevalence rate of stunting in Indonesia is still above $20 \%$, meaning that it has not reached the WHO target which is below 20\% (Teja 2019).

At the national level, Lampung ranks fifteenth for the problem of stunting (Databoks Indonesia 2018; Kementerian Kesehatan Republik Indonesia 2018). And the regencies that are included in the highest order list include the districts of South Lampung, East Lampung and Central Lampung. The government, through the National Medium-Term Development Plan 2010-2014, is determined to reduce the prevalence of undernutrition from $18.4 \%$ to $15 \%$ and reduce the prevalence of stunting and very short under five from $36.8 \%$ to $32 \%$ (Kementerian Kesehatan Republik Indonesia 2018).

Birth weight will have an impact on the growth, development and height of the child at a later age. LBW status will have a high risk of morbidity, mortality, infectious diseases, underweight and stunting in the early fetus to childhood (Wiyogowati 2012). The high rate of LBW is thought to be the cause of the high incidence of stunting in Indonesia. LBW is the most dominant risk factor for stunting in children (Szalatnay, Nurdiati, and Huriyati 2014).

The case of LBW according to data from the Central Statistics Agency of Lampung Province, South Lampung district with a total of 355 people, ranks 3rd after East Lampung and Central Lampung Regencies (Badan Pusat Statistik Provinsi Lampung 2016). The high rate of LBW is thought to be the cause of the high incidence of stunting in Indonesia. LBW is the most dominant risk factor for the incidence of stunting in children (Nadiyah, Briawan, and Martianto 2014).

There are ten villages in South Lampung district that are included in the 1000 priority villages for stunting. Of the ten villages, two are part of the Way Urang Health Center Work Area (Tajimalela Village and Taman Agung Village). And the two villages are in second and third place out of ten priority villages from South Lampung Regency. Village selection is determined by looking at the number of villagers, the number of rural poor people, and the level of village poverty (Kementerian Kesehatan Republik Indonesia 2018).

Seeing the condition of South Lampung district, which is one of the priority districts for stunting control, through the 1000 priority village program. The South Lampung government is committed to dealing with and reducing the prevalence of stunting. In a limited meeting on stunting intervention which was held with the head of the National Team for the Acceleration of Poverty Reduction, it was necessary to strengthen coordination and expand the scope of programs carried out by related Ministries / Agencies to improve the quality of programs to reduce stunting rates in every region that has already been get into the priority village (Kementerian Perencanaan Pembangunan Nasional 2018; Tim Nasional Percepatan Penanggulangan Kemiskinan 2017).

Therefore, the researcher is interested in conducting further research on "the relationship between low birth weight (LBW) and the incidence of stunting in toddlers (aged 24-59 months) in the Way Urang Community Health Center, South Lampung Regency.

\section{RESEARCH METHODS}

This research uses observational analytic methods and case control case studies. This research was conducted in the working area of Way Urang Health Center, South Lampung district (Tajimalela Village, Taman Agung and Merak Belantung) and this research was conducted for 3 months.

The sampling technique used was purposive sampling technique with a sample size of 118 toddlers and was in the working area of Way Urang Health Center, South Lampung Regency.

The inclusion criteria in this study are mothers who have toddlers aged 24 - 59 months, mothers and toddlers who have KIA books, mothers and toddlers who live in the Way Urang Health Center work area and respondents are willing to be the object of research by filling out the informed consent form. The exclusion criteria for this study were mothers and babies who did not have a MCH booklet and babies whose mothers had passed away.

The independent variable in this study is Low Birth Weight (LBW). The dependent variable in this study is the incidence of stunting in children under five in the Way Urang Community Health Center, South Lampung Regency.

The instrument used in this study was the Maternal and Child Health Book (KIA), the data collection method used secondary data in the form of the respondent's Maternal and Child Health Book and the medical records of children with stunting who were in the Way Urang Health Center, Lampung Regency. South. Then the data were analyzed using univariate and bivariate analysis (Chi Square). This study has received approval from the Research Ethics Committee of the Faculty of Medicine, University of Lampung with number 1410 / UN26.18 / PP.05.02.00 / 2020.

\section{RESULTS AND DISCUSSIONS}

In this study, data on Low Birth Weight (LBW) in the Way Urang Community Health Center, South Lampung Regency, can be seen, namely: 
Table 1. Frequency Distribution of LBW History

\begin{tabular}{ccc}
\hline \multicolumn{3}{c}{ History } \\
Characteristics & $\begin{array}{c}\text { Frequency } \\
(\mathbf{n})\end{array}$ & $\begin{array}{c}\text { Percentage } \\
(\mathbf{\%})\end{array}$ \\
\hline LBW & 33 & 28,0 \\
Not LBW & 85 & 72,0 \\
total number & 118 & 100,0 \\
\hline
\end{tabular}

The univariate results in this study obtained data on respondents with a history of low birth weight in children under five, namely 33 under-fives $(28 \%)$ had a history of Low Birth Weight (LBW) and as many as 85 under-fives $(72 \%)$ had no history of Low Birth Weight (LBW).

In this study, it can be seen that the results of the bivariate analysis regarding the relationship between the independent variables and the dependent variable are:

Table 2. The relationship between the history of Low Birth Weight Infants (LBW) with the incidence of stunting

\begin{tabular}{llccc}
\hline & & \multicolumn{2}{c}{ Stunting } & $\mathrm{n}$ \\
& Descriptive & Stunting & $\begin{array}{c}\text { Not } \\
\text { Stunting }\end{array}$ \\
\hline LBW & Count & 22 & 11 & 33 \\
& Expected Count & 16,5 & 16,5 & 33,0 \\
& $\%$ & $66,67 \%$ & $33,33 \%$ & $100 \%$ \\
Not & Count & 37 & 48 & 85 \\
LBW & Expected Count & 42,5 & 42,5 & 85,0 \\
& $\%$ & $43,52 \%$ & $56,47 \%$ & $100 \%$ \\
Total & Count & 59 & 59 & 118 \\
& Expected Count & 59,0 & 59,0 & 118,0 \\
\hline \multirow{4}{*}{} & OR (95\% CI) & $2,595(1,119-6,018)$ \\
& P Value & \multicolumn{3}{c}{0,024} \\
\hline
\end{tabular}

From the description of the table above, it was found that there were $22(66.67 \%) \mathrm{LBW}$ children who were stunted. Meanwhile, among children under five who were not LBW, there were $37(43.52 \%)$ who experienced stunting. The statistical test results obtained $\mathrm{p}$ value $=0.024$, it can be concluded that there is a difference in the proportion of the incidence of stunting between underweight children underweight and under-five underweight (there is a relationship between LBW and stunting). From the analysis, it was also obtained that the OR value $=2.595$, meaning that under-five children who are LBW have a 2.595 times chance of stunting compared to toddlers who are not LBW.

Based on the results of the study, the results of the Chi Square test showed a relationship between low birth weight (LBW) and the incidence of stunting, which showed a significance value ( $p$-value) $<0.05$, which was 0.024 . This means that there is a relationship between Low Birth Weight (LBW) and the incidence of stunting in toddlers (aged 24-59 months) in the Way Urang Community Health Center, South Lampung Regency. The odds ratio value of 2.595 (CI $=95 \% ; 1.119-6.018)$ means that under-five children without LBW have a risk of 2.595 times to suffer from stunting compared to under-five children who are LBW. Of the 59 children under five who suffer from stunting, as many as 37 under five $(43.52 \%)$ are not
LBW. Meanwhile, out of 59 children under five who did not suffer from stunting, as many as 11 children under five $(33.33 \%)$ experienced LBW.

This study supports the existing theory that stunting is a condition where the growth of children under five is failed due to lack of nutritional intake for a long period of time, as a result of giving food that is not in accordance with nutritional needs so that children grow too short for their age. continues in every human life cycle (Kementerian Kesehatan Republik Indonesia 2017). Women of childbearing age and pregnant women who experience chronic energy deficiency will give birth to babies with low birth weight (LBW). LBW will continue to be malnourished toddlers or what is called stunting, and continue to school age with various consequences. This group will become a generation that has lost the golden period of growth and development from without proper response to this group is feared to become a lost generation. Malnutrition in human life needs to be watched carefully, in addition to the impact on child development, this incident usually does not stand alone but is followed by other problems such as deficiency of micronutrients (World Health Organization 2014).

Stunting that has occurred if it is not balanced with catch-up growth results in decreased growth, the problem of stunting is a public health problem associated with an increased risk of illness, death and obstacles to both motor and mental growth. Stunting is formed by inadequate growth faltering and catcth up growth which reflects the inability to achieve optimal growth, this reveals that a group of toddlers who are born with normal weight can experience stunting if their subsequent needs are not met properly (Kementerian Desa Pembangunan Daerah Tertinggal dan Transmigrasi 2017). In everyday life, short toddlers who are understood by rural and urban communities are something normal, not related to children's health problems, generally assume that as long as the child is still active / playing and still has an appetite, even though his height is below normal and stunting is considered as a hereditary factor of parents who are short (Lestari and Kristiana 2018). The types of ingredients and the food menu consumed by people are very much influenced by their culture (Nurbaiti et al. 2014).

This study is also in accordance with the theory that birth weight has a great impact on the growth, development and height of the next child. Babies born with LBW will be at high risk of morbidity, mortality, infectious diseases, underweight and stunting in the early neonatal period to childhood (Wiyogowati 2012). There are some people who argue that rice is the main food, so that, if there is rice, health and growth, although not accompanied by vegetable and animal sources of nutrition (protein) (Nurbaiti et al. 2014).

This study is in line with research by Wiyogowati in (2012) with a cross sectional method with a sample size of 89 children under five. Based on the statistical test, it was found that the relationship between LBW and stunting with the OR value obtained was 1.769 , 
meaning that the incidence of stunting was 1.8 times more likely to occur in respondents who were LBW compared to respondents who were not LBW (Wiyogowati 2012).

Another study conducted by Ebtanasari (2018) explains that there is a relationship between low birth weight and stunting. To determine the relationship between LBW and the incidence of stunting, data processing in this study used the Chi Square Test. This test is used to prove the hypothesis that there is a relationship between LBW and the incidence of stunting in Ketandan Dagang Madiun Village. Based on the results of the Chi Square test with the value of continuity correction, the value of $p=0.00<\alpha=0.05$, it can be said that there is a relationship between LBW and the incidence of stunting (Ebtanasari 2018).

The research by Mei Sari (2017) is in line with this research that there is a relationship between low birth weight and the incidence of stunting where the chi square test results show a significance of 0.000 , this shows that $\mathrm{Ho}$ is rejected and $\mathrm{Ha}$ is accepted, which means that there is a significant relationship between LBW history and the incidence of stunting in children aged 7-12 months $\mathrm{p}$ value $<0.05$ and a strong relationship where the phi value is 0.603 . The results of this study are in accordance with the theory which states that one of the causes of stunting is LBW (Sari 2017).

In several incidents of children under five in the short category (stunting) and malnutrition, initially all were born normal because in their growth, these children are malnourished, this condition can be seen from the recording of nutritional status conducted by Posyandu every month and accompanied by symptoms of infection such as diarrhea and Acute Respiratory Infections (Lestari and Kristiana 2018). During growth, the demands for bone mineralization are very high, very low calcium intake can lead to hypocalcemia, can result in under-mineralization of the new bone deposit matrix and osteoblast dysfunction (Sari et al. 2016). Calcium deficiency will affect linear growth if the calcium content in the bones is less than $50 \%$ of the normal content (Prentice and Bates 1993). In infants, lack of calcium in the bones can cause rickets, while in children, lack of deposits can cause stunted growth. (Gibson et al. 2007).

This is very important to pay attention to in children who are growing, because it can affect their growth and health conditions as adults and in their later life (Sari et al. 2016). Calcium deficiency will affect the bones which have an impact on growth disorders. Lack of calcium in children lack of calcium deposits can cause stunted growth (Burckhardt, DawsonHughes, and Weaver 2010; Peacock 2010). Likewise, the provision of complementary feeding with breastfeeding and with an increase in the quality of food for children at six months (growth mass) and also by improving the quality of ANC services and delivery measures in health care units are very effective in overcoming stunting (Rahmadi 2016; Sutarto et al. 2019). The socio-culture of nutrition during pregnancy includes abstinence from eating squid and stingrays. The prohibition of eating squid for pregnant women has a reason for concern that the baby is difficult to be born because it will go in and out like a squid (Illahi and Muniroh 2018). However, there is a culture of the Acehnese people in maintaining local wisdom in the form of a "mee bu" ceremony, which is a food consisting of rice wrapped in pyramid-shaped young banana leaves and accompanied by side dishes, grilled fish, beef, roasted chicken, curried cooked duck, eggs. , and various types of fruit. This local wisdom is an culture to support the fulfillment of nutrition for pregnant women, and their toddlers, to get their nutrition. Mee bu culture can be an alternative to reduce the prevalence of stunting (Illahi and Muniroh 2018). The traditional belief regarding various taboos and recommendations in relation to the food consumed and the actions of pregnant women have both a positive and negative impact on the health of the mother and the fetus she is carrying (Kasnodihardjo and Lusi Kristiana 2012).

\section{CONCLUSION}

Based on the previous description, the conclusion of this study is that there is a relationship between Low Birth Weight (LBW) and the incidence of stunting in toddlers (aged 24-59 months) in the Way Urang Community Health Center, South Lampung Regency. Other information shows that complementary feeding of breastfeeding for a child for six months (growth mass) is very effective in overcoming stunting, accompanied by improving the quality of health examination services (ANC) during pregnancy and delivery in health care facilities.

\section{REFERENCES}

Badan Pusat Statistik Provinsi Lampung. 2016. "BBLR Di Lampung." Block Caving - A Viable Alternative? (1).

Beatty, Amanda, Nick Ingwersen, William Leith, and Clair Null. 2017. Stunting Prevalence and Correlates among Children in Indonesia. Vol. 2013. Washington, DC:

Burckhardt, Dawson-Hughes, and Weaver. 2010. Nutritional Influences on Bone Health. New York: Springer US.

Casale, D., C. Desmond, and L. Richter. 2014. "Child : The Association between Stunting and Psychosocial Development among Preschool Children : A Study Using the South African Birth to Twenty Cohort Data." Child: Care, Health and Development 40(6):900-910.

Databoks Indonesia. 2018. "Di Mana Provinsi Dengan Stunting Tertinggi 2017?" 2019.

Ebtanasari, Iin. 2018. "Hubungan Berat Badan Lahir Rendah (BBLR) Dengan Kejadian Stunting Pada Anak Usia 1-5 Tahun Di Desa Ketandan 
Kecamatan Dagangan Kabupaten Madiun." 2:227-49.

Gibson, Rosalind S., Mari Skar Manger, Woravimol Krittaphol, Tippawan Pongcharoen, Sueppong Gowachirapant, Karl B. Bailey, and Pattanee Winichagoon. 2007. "Does Zinc Deficiency Play a Role in Stunting among Primary School Children in NE Thailand?" British Journal of Nutrition 97(1):167-75.

Kementerian Desa Pembangunan Daerah Tertinggal dan Transmigrasi. 2017. "Buku Saku Desa Dalam Penanganan Stunting." Buku Saku Desa Dalam Penanganan Stunting 42.

Kementerian Kesehatan Republik Indonesia. 2017. "Penilaian Status Gizi."

Kementerian Kesehatan Republik Indonesia. 2018. "Buletin Stunting." Kementerian Kesehatan RI 301(5):1163-78.

Kementerian Perencanaan Pembangunan Nasional. 2018. "Siaran Pers STUNTING SUMMIT: KOMITMEN BERSAMA TURUNKAN PREVALENSI STUNTING DI INDONESIA."

Lestari, Weny, and Lusi Kristiana. 2018. "Stunting : Studi Konstruksi Sosial Masyarakat Perdesaan Dan Perkotaan Terkait Gizi Dan Pola Pengasuhan Balita Di Kabupaten Jember." Aspirasi 9(1):17-33.

Nadiyah, Dodik Briawan, and Drajat Martianto. 2014. "Faktor Risiko Stunting Pada Anak Usia 0-23 Bulan Di Provinsi Bali, Jawa Barat, Dan Nusa Tenggara Timur." Jurnal Gizi Dan Pangan 9(2):125-132.

Peacock, Munro. 2010. "Calcium Metabolism in Health and Disease." Clin J Am Soc Nephrol 5(23-30):23-30.

Prentice, Ann, and Christopher J. Bates. 1993. "An Appraisal Of The Adequacy Of Dietary Mineral Intakes In Developing Countries For Bone Growth and Development In Children."
Nufrifion Research Reviews 6:51-69.

Rahmadi, Antun. 2016. "Hubungan Berat Badan Dan Panjang Badan Lahir Dengan Kejadian Stunting Anak 12-59 Bulan Di Provinsi Lampung." Jurnal Keperawatan XII(2):209-18.

Sari, Endah Mayang, Mohammad Juffrie, Neti Nurani, and Mei Neni Sitaresmi. 2016. "Asupan Protein, Kalsium Dan Fosfor Pada Anak Stunting Dan Tidak Stunting Usia 24-59 Bulan.” Jurnal Gizi Klinik Indonesia 12(4):152-59.

Sari, Etin Mei. 2017. "Hubungan Riwayat BBLR Dengan Kejadian Stunting Pada Anak Usia 7-12 Bulan Di Desa Selomartani Wilayah Kerja Puskesmas Kalasan.”

Sutarto, Diyah Wulan Sumekar, Sofyan Musabiq Wijaya, and Reni Indriyani. 2019. "Permodelan Probabilitas Kejadian Stunting." JK Unila 3(1):16-20.

Szalatnay, Rafael D., Detty Siti Nurdiati, and Emy Huriyati. 2014. "Berat Badan Lahir Rendah (BBLR) Dengan Kejadian Stunting Pada Anak Usia 6-24 Bulan." Jurnal Gizi Klinik Indonesia 11(1):31-37.

Teja, Mohammad. 2019. "Stunting Balita Indonesia Dan Penanggulangannya." Pusat Penelitian Badan Keahlian DPR RI XI(22):13-18.

Tim Nasional Percepatan Penanggulangan Kemiskinan. 2017. "Buku Ringkasan Stunting."

Wiyogowati, Citaningrum. 2012. "Kejadian Stunting Pada Anak Berumur Dibawah Lima Tahun Tahun (0-59 Bulan) Di Provinsi Papua Barat Tahun 2010 (Analisis Data Riskesdas 2010) Skripsi." 2010:1-101.

World Health Organization. 2014. "Childhood Stunting: Challenges and Opportunities. Report of a Promoting Healthy Growth and Preventing Childhood Stunting Colloquium." WHO Geneva 34. 